Mikhail I.Varentsov ${ }^{1,2,3^{*}}$, Mikhail Y. Grishchenko' and Hendrik Wouters ${ }^{4}$

1 Lomonosov Moscow State University, Faculty of Geography / Research Computing Center, Moscow, Russia

${ }^{2}$ A.M. Obukhov Institute of Atmospheric Physics, Moscow, Russia

${ }^{3}$ Hydrometeorological Research Center of Russia, Moscow, Russia

${ }^{4}$ Ghent University, Department of Forest and Water Management, Ghent, Belgium

*Corresponding author: mvar91@gmail.com

\title{
SIMULTANEOUS ASSESSMENT OF THE SUMMER URBAN HEAT ISLAND IN MOSCOW MEGACITY BASED ON IN SITU OBSERVATIONS, THERMAL SATELLITE IMAGES AND MESOSCALE MODELING
}

ABSTRACT. This study compares three popular approaches to quantify the urban heat island (UHI) effect in Moscow megacity in a summer season (June-August 2015). The first approach uses the measurements of the near-surface air temperature obtained from weather stations, the second is based on remote sensing from thermal imagery of MODIS satellites, and the third is based on the numerical simulations with the mesoscale atmospheric model COSMO-CLM coupled with the urban canopy scheme TERRA_URB. The first approach allows studying the canopy-layer UHI (CLUHI, or anomaly of a nearsurface air temperature), while the second allows studying the surface UHI (SUHI, or anomaly of a land surface temperature), and both types of the UHI could be simulated by the atmospheric model. These approaches were compared in the daytime, evening and nighttime conditions. The results of the study highlight a substantial difference between the SUHI and CLUHI in terms of the diurnal variation and spatial structure. The strongest differences are found at the daytime, at which the SUHI reaches the maximal intensity (up to $10^{\circ} \mathrm{C}$ ) whereas the CLUHI reaches the minimum intensity $\left(1.5^{\circ} \mathrm{C}\right)$. However, there is a stronger consistency between CLUHU and SUHI at night, when their intensities converge to $5-6^{\circ} \mathrm{C}$. In addition, the nighttime CLUHI and SUHI have similar monocentric spatial structure with a temperature maximum in the city center. The presented findings should be taken into account when interpreting and comparing the results of UHI studies, based on the different approaches. The mesoscale model reproduces the CLUHI-SUHI relationships and provides good agreement with in situ observations on the CLUHI spatiotemporal variations (with near-zero biases for daytime and nighttime CLUHI intensity and correlation coefficients more than 0.8 for CLUHI spatial patterns). However, the agreement of the simulated SUHI with the remote sensing data is lower than agreement of the simulated CLUHI with in situ measurements. Specifically, the model tends to overestimate the daytime SUHI intensity. These results indicate a need for further in-depth investigation of the model behavior and SUHI-CLUHI relationships in general.

KEY WORDS: urban heat island, UHI, SUHI, urban climate, mesoscale modelling, remote sensing, thermal satellite images, land surface temperature, Moscow, MODIS, COSMO 
CITATION: M.I. Varentsov, M. Yu. Grishchenko and H. Wouters (2019) Simultaneous assessment of the summer urban heat island in Moscow megacity based on in situ observations, thermal satellite images and mesoscale modeling. Geography, Environment, Sustainability, Vol.12, No 4, p. 74-95

DOI-10.24057/2071-9388-2019-10

\section{INTRODUCTION}

An essential climatological feature of most urban environments is the positive temperature deviation from the rural surroundings, which is known as the urban heat island (UHI) effect (Oke 1982). The relevance of UHI studies is related to its impacts on ecosystems (Esau and Miles 2016), assets and services of human society such as damage to infrastructure and heating/ cooling demands (Davies et al. 2008) and, most importantly, health and comfort of the urban population (Buechley et al. 1972; Dousset et al. 2011; Tan et al. 2010a). Nowadays, UHI studies mainly use three types of data: in situ temperature observations, remote sensing data (thermal satellite images) and climate model simulations, which are described below.

Regular in situ temperature observations are practiced at regular weather stations of national hydrometeorological services and other observational networks. They are usually made at the height of $2 \mathrm{~m}$ above the ground registering the near-surface air temperature (hereafter referred as SAT). SAT is one of the essential applied climate variables (GCOS 2010) used, apart from other calculations, in the calculation of biometeorological indices (Emelina et al. 2014). However, the regular weather stations are usually located outside of the urban areas or in urban parks that makes the data of such observations inappropriate for urban climate studies (Peterson 2003). Dense urban meteorological networks are created for scientific and monitoring purposes (e.g. Konstantinov et al. 2018), but only in a few dozens of cities around the world (Muller et al. 2013).

Remote sensing data is used to derive land surface temperatures (hereafter referred as LST) by the processing of thermal satellite images. In contrast to highly fragmented in situ measurements, satellite images provide a continuous and global spatial coverage. Such data can be subdivided into two types: high spatial resolution data recorded by ASTER, ETM +, TIRS imaging systems, and low resolution data obtained by MODIS, AVHRR and some others. Both data types have their advantages: the high-resolution data allows studying thermal structure of urban landscapes in more detail (Zhu et al. 2002; Sobrino et al. 2012; Baldina and Grishchenko 2014), whereas the low-resolution data offers a much higher sample frequency up to first dozens of minutes (Cheval and Dumitrescu 2017).

It is important to note that remote sensing and in situ data characterize different meteorological variables: the land surface temperature (LST) and the near-surface air temperature (SAT). These variables are generally different from each other, and their relationship is complex from a theoretical and empirical perspective (Yang et al. 2017). For example, on a hot summer day, LST can reach $60-70^{\circ} \mathrm{C}$ while SAT remains at about $30-35^{\circ} \mathrm{C}$ (Gornyy et al. 2016; Sobrino et al. 2012). The UHI effect is pronounced in the field of both variables, however the urban LST and SAT anomalies have different patterns of spatial and temporal (diurnal and seasonal) variations (Voogt and Oke 2003; Sheng et al. 2017; Sun et al. 2015). Due to such differences, the UHI signal in LST (hereafter referred as surface UHI or SUHI) and UHI signal in SAT (hereafter referred as canopy-layer UHI or CLUHI) are usually treated separately in modern urban climate studies (Voogt and Oke 2003).

Historically, the UHI has been discovered and studied for a long time as an anomaly of in situ observations of SAT at urban sites compared to rural areas. However, the rapid development of remote sensing technolo- 
gies results in a recent exponential increase 을 of SUHI studies (Zhou et al. 2018). Remote sensing data is now being used in a large number of SUHI studies, including the researches of the SUHI climatology (Choi et al. 2014; Miles and Esau 2017; Peng et al. 2012; Zhou et al. 2013) and spatial structure (Zhou et al. 2017) on the global or regional scale, and in more detailed theoretical and applied studies for specific cities. For example, Shen et al. (2016) and Gorny et al. (2016) used the high-resolution remote sensing data on LST to assess the urban climate change in Wuhan (China), Saint-Petersburg (Russia) and Kiev (Ukraine). Dousset et al. (2011) applied the remote sensing LST data to correlate environmental factors with a heat-related mortality for Paris during a heat wave. Another example is a series of urban climate studies for the city of Bucharest (Cheval and Dumitrescu 2015, 2017).

In most SUHI studies the authors note the significant differences between SUHI and CLUHI, but such difference does not prevent authors from making fundamental or applied conclusions on urban climatology. At the same time, the relationship between the SUHI and CLUHI still requires further detailed study (Zhou et al. 2018).

Rapid development of computing technologies and numerical methods for representing the processes occurring in the atmosphere have opened wide opportunities for application of the numerical modelling methods in urban climate studies. Mesoscale atmospheric models use a horizontal grid step of a few $\mathrm{km}$. They are able to simulate the meteorological regime of a big city (see e.g. Martilli et al. 2002; Bohnenstengel et al. 2011; Wouters et al. 2016) with high spatial and temporal resolution, including the $\mathrm{UHI}$ effect and urban-induced mesoscale circulations, which are known as "urban breezes" (Lemonsu and Masson 2002). Such models could be used for assessing the urban climate change scenarios (Krayenhoff et al. 2018; Wouters et al. 2017). However, practical and scientific applications of such models require their accurate calibration and verification by comparing the results obtained from the models and from the observations. Remote sensing data al- lows verifying the models for areas, including the urban ones that are not covered by in situ observations. However, the experience of using the remote sensing data for verification of the mesoscale models for urban areas is very limited due to a number of problems, which are related to the presence of clouds, to the LST dependence from the sensor view angle and to the anisotropy of a three-dimensional urban geometry (Hu et al. 2014).

Thus, in situ temperature observations, remote sensing data and modelling methods are actively used to study the UHIs. All of the approaches have benefits and shortcomings that are summarized in Table 1. Quite often, these approaches are used together (e.g. Konstantinov et al. 2015; Mariani et al. 2016; Sheng et al. 2017). However, there is a lack of studies focused on assessment of the contrasting behavior of the SUHI and CLUHI, and the models performance in reproducing such features. Moreover, such a comparison has never been carried out for Moscow megacity, despite the abundance of the UHI studies for Moscow within the framework of each of the considered approaches (e.g. Grishchenko 2012; Climate of Moscow... 2017; Lokoshchenko 2014).

Here, we present the simultaneous assessment of the surface UHI and canopy-layer $\mathrm{UHI}$ and their contrasting dynamics based on three quantitative methods, namely in situ observations, thermal satellite images and high-resolution regional climate modelling. We use the data on in situ SAT observations obtained from a dense network of weather and air-quality stations in the Moscow region to quantify the CLUHI and MODIS thermal satellite images to quantify the SUHI. We use the regional climate model COSMO-CLM (Rockel et al. 2008), coupled with the specific urban canopy scheme TERRA_URB (Wouters et al. 2016) to simulate the meteorological regime of the Moscow region, including the both types of the UHI, with a high (1 km) spatial resolution.

The aim of the study is the qualitative and quantitative comparison of the UHI features, which are evaluated according to the three considered methods, and analysis of their differences. We consider summer conditions, for 
Table 1. A brief summary of the benefits and shortcomings of the three considered approaches to quantify the UHI

\begin{tabular}{|c|c|c|c|}
\hline $\begin{array}{l}\text { Approach to } \\
\text { study the UHI }\end{array}$ & $\begin{array}{c}\text { Analyzed } \\
\text { variable and } \\
\text { UHI type }\end{array}$ & Benefits & Shortcomings \\
\hline $\begin{array}{c}\text { In situ } \\
\text { meteorological } \\
\text { observations }\end{array}$ & $\begin{array}{c}\text { SAT (other } \\
\text { measured } \\
\text { weather } \\
\text { parameters are } \\
\text { also available); } \\
\text { CLUHI }\end{array}$ & $\begin{array}{l}\text { The most precise data on air } \\
\text { temperature with relatively } \\
\text { high and regular temporal } \\
\text { resolution, e.g. } 3 \text { hours for } \\
\text { the most of regular weather } \\
\text { stations }\end{array}$ & $\begin{array}{l}\text { (1) irregular and discontinuous } \\
\text { spatial coverage, which is } \\
\text { usually especially poor in } \\
\text { urban areas; } \\
\text { (2) limited data access }\end{array}$ \\
\hline $\begin{array}{c}\text { Thermal } \\
\text { satellite images }\end{array}$ & LST; SUHI & $\begin{array}{l}\text { (1) continuous and near- } \\
\text { global spatial coverage; (2) } \\
\text { high spatial resolution, e.g. } 1 \\
\text { km for MODIS system; } \\
\text { (3) easy data access }\end{array}$ & $\begin{array}{l}\text { (1) limited and irregular } \\
\text { temporal resolution, e.g. } 2 \\
\text { daytime and } 2 \text { nighttime } \\
\text { images per day for MODIS } \\
\text { system; } \\
\text { (2) data is available only for } \\
\text { cloud-free conditions }\end{array}$ \\
\hline $\begin{array}{l}\text { Mesoscale } \\
\text { atmospheric } \\
\text { modelling }\end{array}$ & $\begin{array}{c}\text { SAT and LST } \\
\text { (other modelled } \\
\text { atmospheric, } \\
\text { surface and soil } \\
\text { variables are also } \\
\text { available); CLUHI, } \\
\text { SUHI and UHI in } \\
\text { the ABL }\end{array}$ & $\begin{array}{c}\text { (1) continuous spatial } \\
\text { coverage; (2) high spatial } \\
\text { and temporal resolution, } \\
\text { e.g. } 1 \text { km and } 1 \text { hour; (3) } \\
\text { an opportunity to access } \\
\text { data on dozens modelled } \\
\text { variables for different vertical } \\
\text { levels; } \\
\text { (4) an opportunity to change } \\
\text { the model settings, land-use } \\
\text { data, etc. in order to study } \\
\text { the model responses to } \\
\text { these changes }\end{array}$ & $\begin{array}{l}\text { (1) the model simulations } \\
\text { require the computational } \\
\text { resources and the external } \\
\text { data (initial and boundary } \\
\text { conditions, land-use data, etc.); } \\
\text { (2) high-resolution simulations } \\
\text { are possible only for a limited } \\
\text { area; } \\
\text { (3) the models are not perfect } \\
\text { and may strongly deviate from } \\
\text { reality; } \\
\text { (4) model verification is a } \\
\text { necessary part of a model- } \\
\text { based study }\end{array}$ \\
\hline
\end{tabular}

which the UHI studies are more relevant, due to the negative UHI impact on the biometeorological comfort. The summer of 2015 was selected because of the availability of the in situ data for the biggest number of sites, including several new automatic weather stations.

The study is structured as follows. The next section (Data and Methods) provides a detailed description of in situ observations, remote sensing data and modelling techniques. Section Results presents the results of the comparison of three quantitative methods. Section Discussion interprets and discusses the revealed differences between the methods. The last section (Conclusion) is the conclusion; it gives the practical recommendation for applied studies and actualizes the needs for further theoretical studies.

\section{DATA AND METHODS}

\section{The study area and in situ observations}

The city of Moscow is the biggest monocentric urban agglomeration in Russia and Europe with a population of about 16-17 million people (Cox 2018). The area of the city (administrative unit of Russia) is $2561 \mathrm{~km}^{2}$, however it includes a wide area known as "New Moscow", which was joined to the city in 2011, but remains practically unbuilt. The actual area of the city (excluding the suburbs and satellite cities) is about $1000 \mathrm{~km}^{2}$. Moscow is densely built with the midrise and high-rise block-houses. According to the popular classification of Stewart and Oke (2012), the prevailing types of local climate zones (LCZs) in Moscow are LCZ 5 (compact midrise) and LCZ 
6 (open high-rise), while the historical city

center is mostly covered by LCZ 2 (compact midsize) and several industrial areas (LCZ 10) are scattered within the city (Samsonov and Trigub 2018). There are a number of parks and urban forests in the city, including the two biggest ones, Losiny Ostrov National Park in the north-eastern part of the city and Bitsa Park in the southern part of the city. The area around the megacity is mostly covered by forests or croplands. The only big water bodies in the Moscow region are the water reservoirs located to the north of Moscow.

The city of Moscow serves as an optimal testbed for urban climate studies due its size, flat and homogeneous surrounding terrain, compact and relatively symmetric shapes. The dense meteorological network provides for in situ observations in the city and in its surroundings. Long-term meteorological observations are carried out at regular weather stations (hereafter referred as WSs) of the national hydrometeorological service (Roshydromet). Several WSs are located within the urban area, including Balchug WS in the city center and meteorological observatory of Lomonosov Moscow State University (MSU) in an urban park. More recent and denser networks include automatic weather stations (hereafter referred as AWSs) of the national hydrometeorological service and automatic air-quality stations (hereafter referred as AAQS) of Budgetary Environmental Protection Institution "Mosecomonitoring". The AWS network has been developed since 2012, whereas the AAQS network - since the 1990s. Meteorological observations at the AAQSs do not comply with the standards of the World Meteorological Organization (WMO) (e.g. the sensors are located at $4 \mathrm{~m}$ above the ground instead of $2 \mathrm{~m}$ as directed by WMO standards). Hence, AAQS data should be used with caution. However, previous studies have shown that AAQS observations are suitable for the analysis of the UHI in terms of the daily-mean or mean nighttime temperatures (Climate of Moscow... 2017).

In our study, we use regular SAT observations on 3-hourly intervals at 16 WSs (including 5 airport WSs), 11 AWSs and 37 AAQSs located in Moscow and its surroundings (Fig. 1). The basic study area is selected according to the location of these stations. It spans an area between 55.35 and $56.07^{\circ} \mathrm{N}$, and between 36.68 and $38.73^{\circ} \mathrm{E}$. Further comparison of three considered approaches is performed for this region. In addition, we use observations at 6 WSs located outside the central

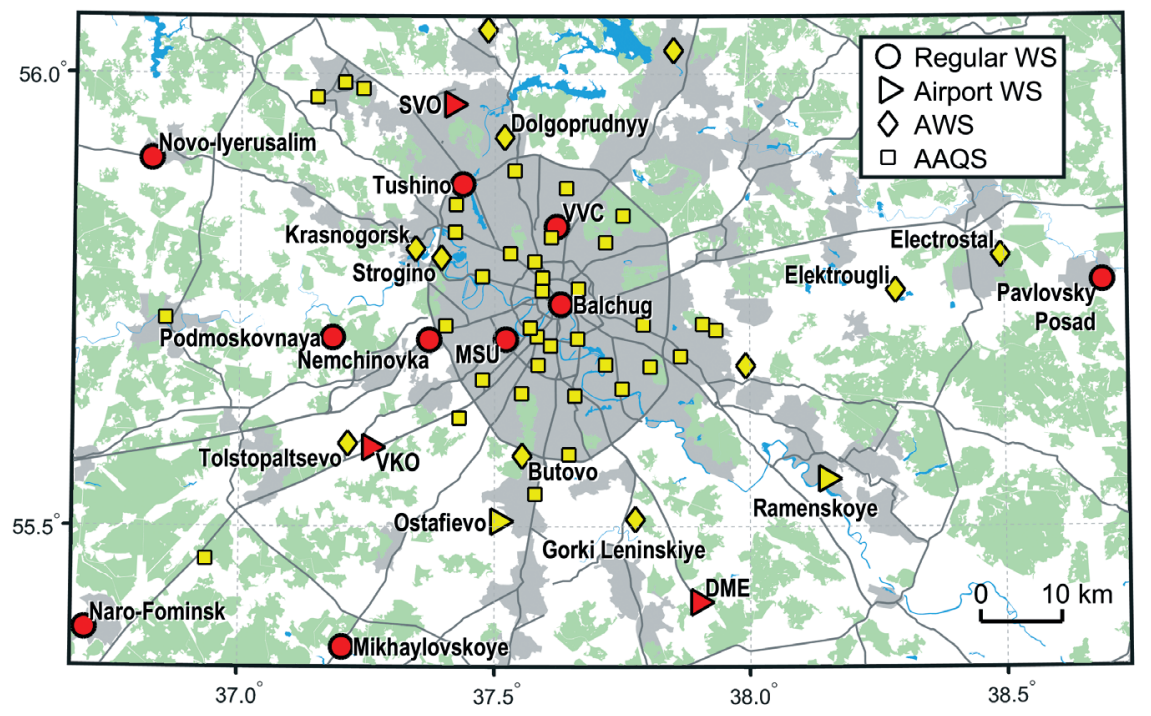

Fig. 1. Location of the weather stations, AWSs and AAQSs within the basic study area. Red color indicates the weather stations with long-term observation data, yellow color indicates the new observation sites (AWSs, AAQSs and two new airports). Urban areas, forests and primary highways are shown according to OpenStreetMap data 
study region (Fig. 2) to evaluate the UHI intensity according to in situ observations. All observational data were collected in a single database and processed by quality control and gap filling routines; see details in (Climate of Moscow... 2017).

In situ LST observations are also carried out at the number of WSs. However, they are not carried out at the AAQSs. It should be noted that the measured LST characterizes the local conditions at the point of measurement and may not correspond to typical conditions of the surrounding landscape, especially for urban conditions. For these reasons, in situ data on LST is not used in our study.

\section{Satellite images}

As satellite data on the surface temperature, we use the data of the MODIS (Moderate Resolution Imaging Spectroradiometer) sensor operating on the Terra and Aqua satellites, namely the MOD11A1 and MYD11A1 rasters (data collection 6 ) with a grid spacing of $1 \mathrm{~km}$. The MODIS sensor captures images in 36 channels of the visible, near infrared, short-wave infrared and thermal infrared ranges of the spectrum. The LST is determined from the channels 31 and 32 (10.7811.28 and 11.77-12.27 $\mu \mathrm{m}$, respectively) in the range that accounts for the maximum of the Earth's radiation (10-12 $\mu \mathrm{m})$. This data is available on the NASA Earthdata web-portal (https://earthdata.nasa.gov/). The LST values for the daytime and nighttime images are contained in the LST_Day_ $1 \mathrm{~km}$ and LST_Night_ $1 \mathrm{~km}$ layers, respectively. For the Moscow region, the registration time of daytime (nighttime) Terra images is approximately 11:30 (21:50) MSK, for Aqua images - approximately 12:40 (02:30) MSK. Hence, MODIS data can be used for UHI studies for daytime (Terra and Aqua images), evening (Terra) and nighttime (Aqua) conditions. The zenith angle for the most of images is $25-30^{\circ}$.

For the further analysis, we selected images with a cloud cover less than 25\% within the analyzed area, within a radius of $25 \mathrm{~km}$ and $10 \mathrm{~km}$ from the center of Moscow (three conditions must be fulfilled simultaneously). In total, we selected 21 daytime and 9 nighttime images from the Terra satellite, 19 daytime and 14 nighttime images from the Aqua satellite over the summer of 2015. Based on the selected images, the average LST was calculated. In order to avoid distortion of the average LST by gaps in the data, related with remaining cloud-covered pixels, data for such pixels was restored using the linear interpolation method from the data on the neighboring pixels.

\section{Regional mesoscale modelling}

We use the limited-area mesoscale model COSMO-CLM (Rockel et al. 2008) to simulate the meteorological regime of the Moscow region. The model is developed by the COSMO international consortium (Consortium for Small-scale Modelling, www. cosmo-model.org) and used for numerical weather prediction in many countries of the world, including Russia (Vil'fand et al. 2010). The COSMO-CLM version of the model is adapted for long-term simulations (Rockel et al. 2008). It is developed by the CLM community (www.clm-community.eu) and frequently used for regional climate studies. The model provides a numerical solution of nonhydrostatic thermo-hydrodynamical equations describing compressible flow in a moist atmosphere with given initial and boundary conditions. Thermal and humidity regime of the soil active layer is simulated by the TERRA module, which takes into account heat and humidity transport, evapotranspiration and other processes in the soil (Doms et al. 2011). Hence, the land surface temperature, which is important in our study, is a prognostic variable of the model.

The COSMO-CLM model is used in our study for a dynamic downscaling of the ERA-Interim reanalysis data (Dee et al. 2011) for the Moscow region. We use nested modelling domains D1, D2 and D3 (Fig. 2) with a grid spacing of 12,3 and $1 \mathrm{~km}$, respectively. These grids are designed in a rotated geographical coordinate system, where the origin $\left(0^{\circ} \mathrm{N}, 0^{\circ} \mathrm{E}\right)$ is moved to the center of Moscow. The inner model domain D3 covers the area of $180 \times 180 \mathrm{~km}$ around Moscow center. A more detailed description of the simulations for Moscow is presented in previous studies (Varentsov et al. 2017a; 2017b; 
2018). It includes the description of the calibrated configuration of the model reducing the systematic biases. The simulations are performed for the period from $1^{\text {st }}$ May to $31^{\text {st }}$ August 2015.

The urban canopy model (UCM) TERRA_URB (Wouters et al. 2016) is used to take into account the urban physics in terms of surface energy and moisture exchanges including the influence of street-canyon geometry. TERRA_URB scheme provides the corrections of the surface parameters (roughness length, albedo, emissivity, heat capacity, etc.) within the framework of TERRA module using the semi-empirical urban canopy dependences. In contrast to more complex UCMs such as TEB or BEM schemes (Martilli et al. 2002; Masson 2000), TERRA_URB scheme does not consider the road, roof and wall surfaces separately. Instead, the city is considered as a horizontal surface with radiative and thermodynamic properties that complies to the structure of the urban canopy. The anthropogenic heat flux (AHF) is parameterized according to (Flanner 2009)

(a)

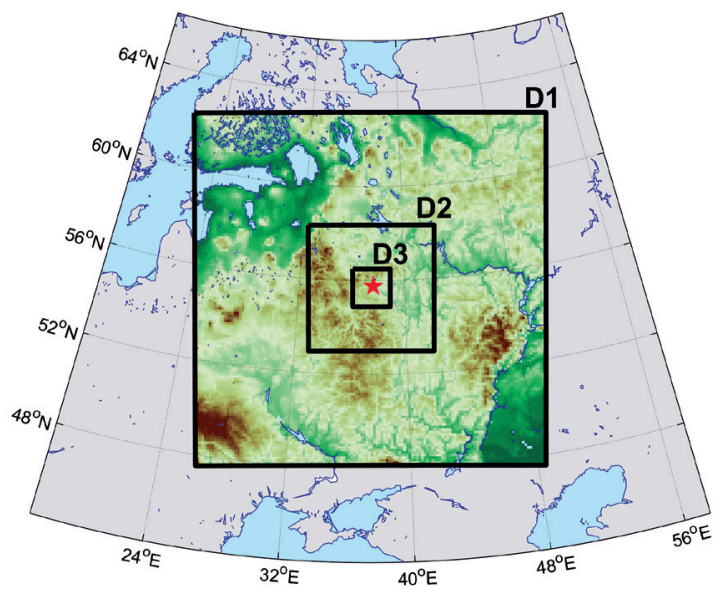

(b)

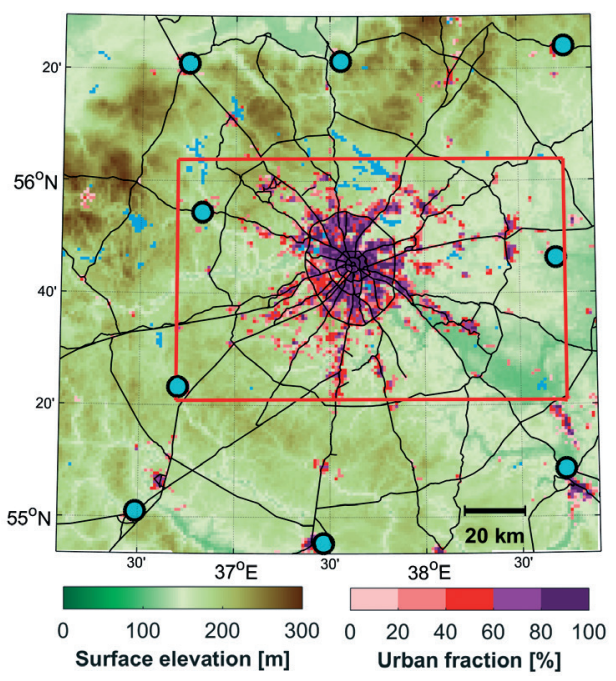

Fig. 2. The cascade-nested domains D1, D2 and D3 of the simulations with the COSMO-CLM model, with surface elevation is indicated by the color scale, and water surfaces - by the light-blue color (a). The detailed map of the inner D3 domain with urban fraction is indicated by an additional color scale (b). The cyan circles in (b) indicate the location of the WSs used for mean rural temperature assessment, the red rectangle indicates the basic study area that corresponds to Fig. 1. Black lines in (b) indicate the primary road network according to OpenStreetMap data 
taking into account the annual-mean value together with its typical diurnal and annual variations and the dependence of its annual amplitude on the latitude. To describe the heterogeneity of the urban surface, TERRA URB implements the so-called tile approach, for which urbanized and natural parts can coexist in each grid cell of the model. Hence, the LST and SAT values, heat fluxes and other soil or surface variables are simulated separately for natural and urban tiles in each grid cell of the model. The average values for each grid cell are calculated taking into account the area fraction of urban and natural tiles.

The application of the TERRA_URB scheme requires the definition of several urban canopy parameters for each grid cell of the model. These parameters are: urban area fraction (UF), annual-mean AHF, roof area fraction, mean building height $(\mathrm{H})$ and $\mathrm{H} / \mathrm{W}$ ratio, where $\mathrm{W}$ is mean street width. We use original method of GIS-based analysis of OpenStreetMap data to obtain these parameters (Samsonov et al. 2015; Varentsov et al. 2017b). The estimation of the mean annual AHF for each grid cell of the model is based on the estimate of its city-average value of $75 \mathrm{Wt} / \mathrm{m}^{2}$ (Stewart and Kennedy, 2017). The spatial distribution of the urban fraction is shown in Fig. 2b. According to Wouters et al. (2016), thermal and radiative properties (albedo, emissivity, heat capacity and heat conductivity) of the urban materials are defined as constants over the urban area with minor changes (albedo of the urban substrate was set to 0.15; volumetric heat capacity was set to $1.6 \cdot 106 \mathrm{~J} \cdot \mathrm{K}^{-1} \cdot \mathrm{m}^{-3}$; heat conductivity to 0.8 $\left.\mathrm{W} \cdot \mathrm{K}^{-1} \cdot \mathrm{m}^{-1}\right)$

The model output contains dozens of meteorological parameters, related to the atmosphere, soil and land surface. In our study we use the modelled SAT and LST values, available on 1-km grid of D3 domain with 1-hour intervals.

\section{Methodology for comparison of the three temperature data types}

The comparison of the three considered approaches requires a geographical consistency between the two gridded datasets
(MODIS images and COSMO-CLM simulations) and the in situ observations. Since the MODIS data and modelling results are available on different grids, we use bicubic interpolation to transfer MODIS data onto the projection and the grid used in the COSMO-CLM model. The further analysis uses the COSMO-CLM grid. In order to take into account possible discrepancies between the land-use data of the model grid and the actual location of the observational sites, a following method is applied. The comparison of the modelling results and in situ observations is performed for the model grid cells that are selected among 9 nearest grid cells taking into consideration the land use type (e.g. WS in urban environment was compared with a grid cell with a high urban fraction) (see details in Varentsov et al. 2017a). The same grid cells are used for the comparison of the in situ and remote sensing data. Modelling results available on hourly intervals and in situ data available on three-hourly intervals are interpolated in time for the registration time of MODIS satellite images.

\section{RESULTS}

\section{Moscow UHI according to remote sens- ing data and in situ observations}

In this section, the Moscow SUHI according to MODIS-derived LST data averaged over the selected cloud-free satellite images is analyzed and compared with in situ SAT observations. In order to quantify the SUHI, we define the LST anomaly $(\triangle \mathrm{LST})$ as departure from the mean LST value (T0), which is averaged over all rural grid cells within the study area. Grid cells are classified as rural if they are located outside of the $1 \mathrm{~km}$ (1 grid cell) buffer around the urban cells (with urban fraction $>0$ ).

The intensive SUHI is clearly identified both for daytime, evening and nighttime conditions (Fig. 3). The mean maximum $\triangle$ LST reaches approximately $10^{\circ} \mathrm{C}$ at daytime, $5.5^{\circ} \mathrm{C}$ at evening and $6^{\circ} \mathrm{C}$ at night. However, there is a clear difference between the spatial structure of the daytime and evening/ nighttime SUHIs. The daytime LST field is characterized by high spatial variability 
(a)

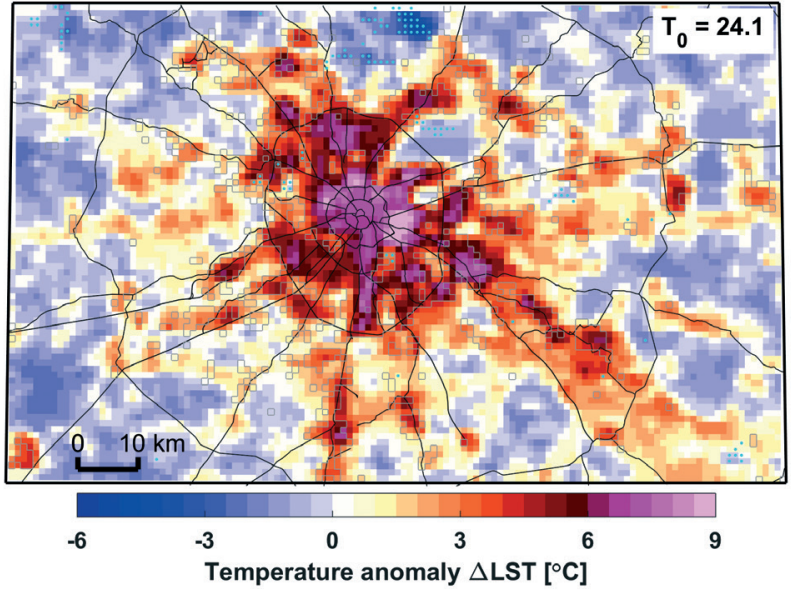

(b)

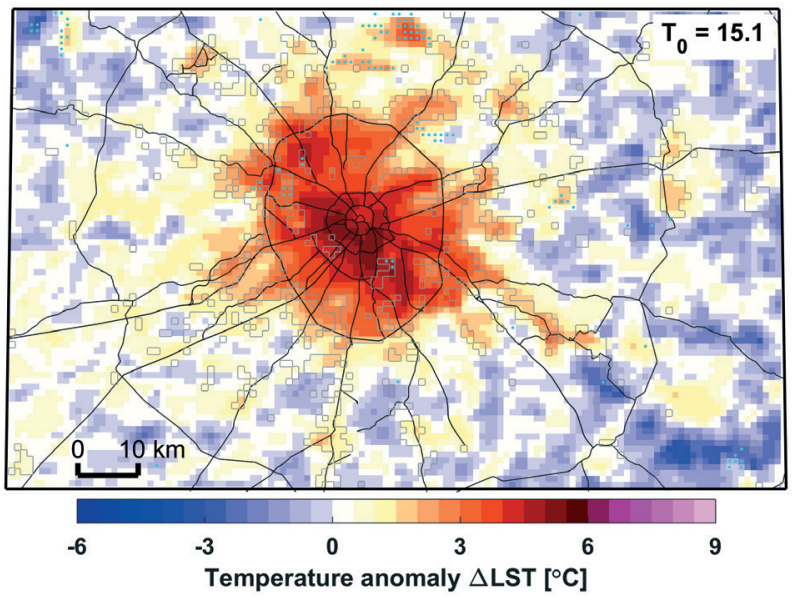

(c)

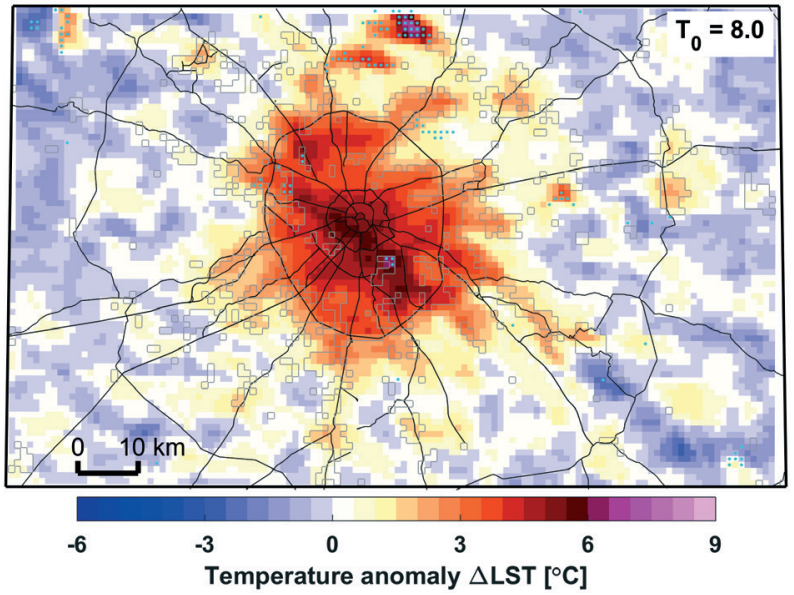

Fig. 3. Anomalies of the Land surface temperature ( $\Delta L S T)$ according to MODIS data, averaged over selected daytime (a) and evening (b) Terra images and nighttime Aqua images (c). Anomaly is defined as a difference between the LST and its mean rural value T0 (see details in text). Black lines indicate the primary highways according to OpenStreetMap data, gray contours indicate urban grid cells, cyan points indicate water grid cells 
and sharp gradients between the urban and non-urban areas. The pronounced LST anomalies are found in all urban areas, including the city edges and small satellite towns around Moscow, and there are several isolated hotspots within the city. At the same time, the urban parks and green areas appear as cool as rural landscapes outside of the megacity. The evening/nighttime LST field is smoother. The nighttime SUHI is shaped as monocentric temperature anomaly, where the area of maximum temperatures is located in the central part of the city and extends from the northeast to the south-west. The city center is significantly warmer than urban periphery and satellite towns. Moreover, the positive anomaly is distributed over the few kilometers outside of the urban areas. In contrast to daytime conditions, the urban parks are warmer than rural areas outside of the city.

The principal difference between the daytime and nighttime conditions is also found in terms of relationship between the MODIS-derived SUHI and CLUHI, evaluated according to in situ data (Fig. 4). The spatial patterns of the evening/nighttime SUHI and CLUHI are highly correlated $\left(R^{2}>\right.$
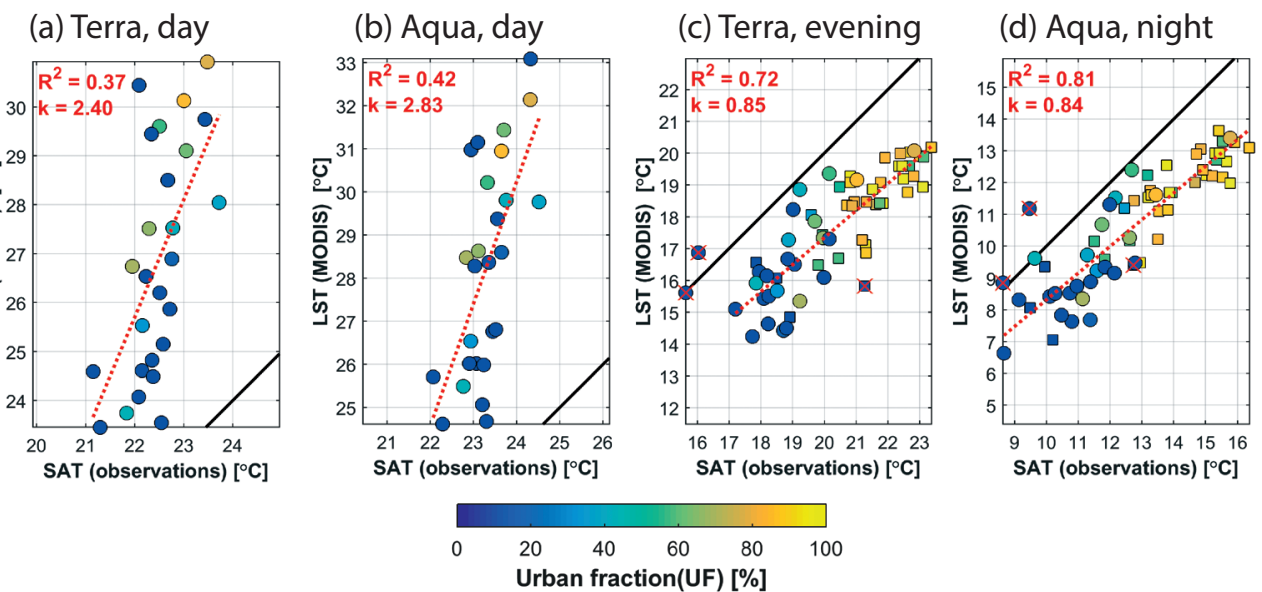

0.7), and the range of urban-rural LST and SAT differences is quite similar. Indeed, the evening/nighttime SAT in the city center (Balchug WS and nearest AAQSs) is $5-6^{\circ} \mathrm{C}$ higher than in the rural areas, which is consistent with evening/nighttime $\Delta$ LST maxima. In contrast, the correlation between SAT and LST spatial patterns is much lower during the daytime $\left(R^{2} \approx 0.4\right)$, while the LST spatial variability is 2-3 times higher than SAT variability. The city center is only $1.5^{\circ} \mathrm{C}$ warmer than the rural areas (on average) during the daytime in terms of air temperatures, while the urban LST anomalies exceed $10^{\circ} \mathrm{C}$.

Comparison of the modelling results, remote sensing and in situ data

The revealed difference between the daytime and nighttime SUHI-CLUHI relationships is based on the comparison of the MODIS LST data with a continuous spatial coverage and in situ SAT observations that are highly fragmented in space. We further use the modelling results to check the revealed SUHI-CLUHI relationships based on the data with a continuous spatial coverage. In addition,

\section{$\begin{array}{ll}\text { (c) Terra, evening } & \text { (d) Aqua, night }\end{array}$}

Fig. 4. Relation between LST and SAT values according to in situ observation and MODIS remote sensing data, averaged over selected daytime $(a, b)$ and evening (c) and nighttime (d) Aqua/Terra images. Circle markers indicate AAQSs, square markers indicate WSs and AWSs. AAQS data is not used for daytime conditions. Color indicates the urban fraction in the corresponding model grid cells. Red lines indicate linear trends. The coefficient of determination $\left(R^{2}\right)$ and slope $(k)$ of the linear trends are shown for each panel. Red crosses indicate points that were excluded from linear regression due to the specific microclimatic features of corresponding sites. Solid black lines are one-to-one lines 
we consider the opportunity to use MODIS LST data for the model verification as an additional verification to the one that is based on in situ observations.

Prior to comparison of the modelling results and MODIS data, it is important to highlight the key results of the model-observation comparison for air temperature and other meteorological parameters, which are presented in details in previous studies (Varentsov et al. 2017a, 2017b, 2018). Such comparison has shown that the model successfully reproduces the summertime meteorological regime of the Moscow region including the temporal variability of mean rural temperature and CLUHI intensity for the city center, including the diurnal and synoptic-scale variations and extremes of CLUHI intensity that reaches $8-9^{\circ} \mathrm{C}$ at calm and clear nights (Fig. 5). The model also adequately simulates the spatial structure of the CLUHI in field of mean summer temperature (Fig. 6). Approximately the same agreement is found between the observed and simulated SAT values, averaged over the specific moments of registration of the selected satellite images (not shown).

The fields of modelled SAT and LST, averaged over the moments of registration of
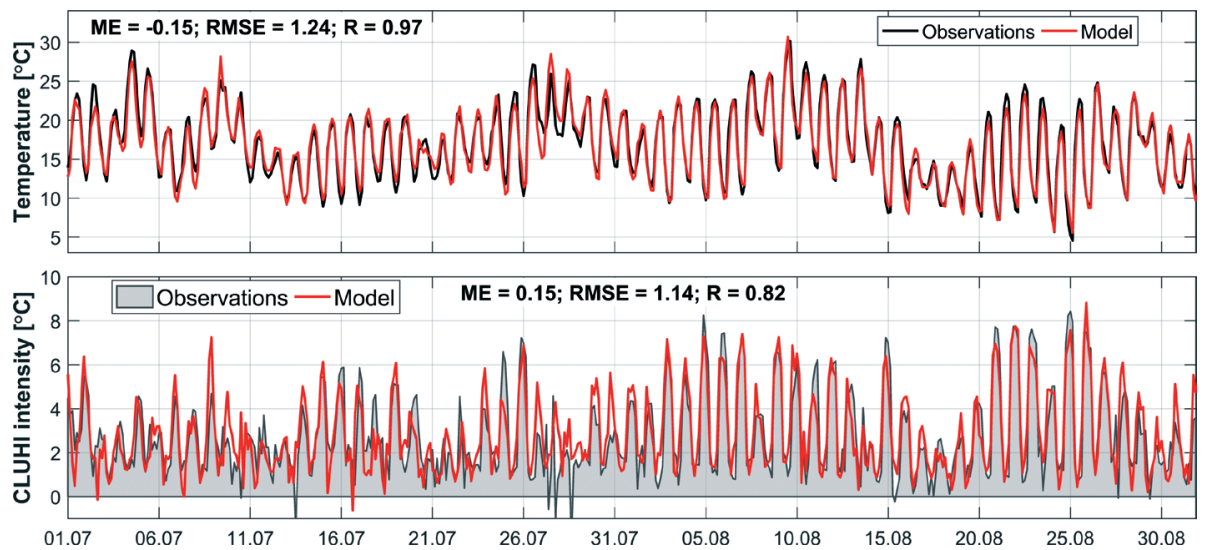

Fig. 5. Temporal variation of the mean rural air temperature (top panel) and CLUHI intensity for Balchug WS in the city center (lower panel) according to in situ observations and modeling results during July-August 2015. Mean rural temperature is averaged for each moment over nine rural WSs around Moscow (Fig. 2b); CLUHI intensity is defined as the difference between the temperature at the urban station and the mean rural value. The mean error $\left(\mathrm{ME},{ }^{\circ} \mathrm{C}\right)$, root-mean square error $\left(\mathrm{RMSE},{ }^{\circ} \mathrm{C}\right)$ and correlation coefficient $(\mathrm{R})$ for modelobservation comparison are shown for each panel
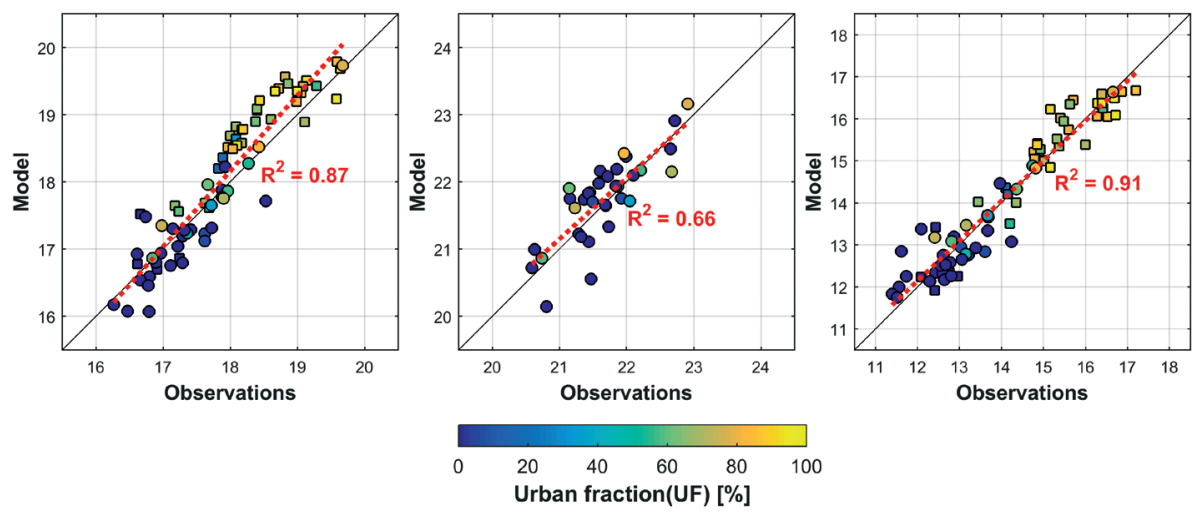

Fig. 6. Comparison of the observed and modelled SAT values for daily-mean (left panel), daytime (15:00 MSK, center panel) and nighttime (03:00 MSK, right panel) values, averaged over the summer of 2015. Designations are similar to Fig. 4. The coefficient of determination of the linear trend $\left(R^{2}\right)$ is shown for each panel. Solid black lines are one-to-one lines 
the selected Terra images, are presented in Fig. 7. Generally, the modelling results are consistent with MODIS remote sensing data (Fig. 3) in terms of spatial structure of LST fields and SUHI spatial patterns. The agreement is also found for the moments of registration of the selected Aqua images (not shown). However, the modelled SUHI intensity largely exceeds the MODIS-derived values: the modelled urban-rural LST differences exceed $16^{\circ} \mathrm{C}$, while the urban LST anomaly according to MODIS data does not exceed $10^{\circ} \mathrm{C}$. The modelled SUHICLUHI relationships confirm the results that are obtained based on MODIS data and in situ observations. The CLUHI and SUHI are almost equally intensive at evening and night, and their spatial patterns are strongly correlated. $\mathrm{R}^{2}$ coefficient of the correlation between the modelled SAT and LST is higher than 0.85 both for considered mean nighttime and evening fields, both for urban and rural areas. At the daytime the pronounced SUHI is loosely correlated with a weak CLUHI, $R^{2}<0.3$. Moreover, the day-

(a)

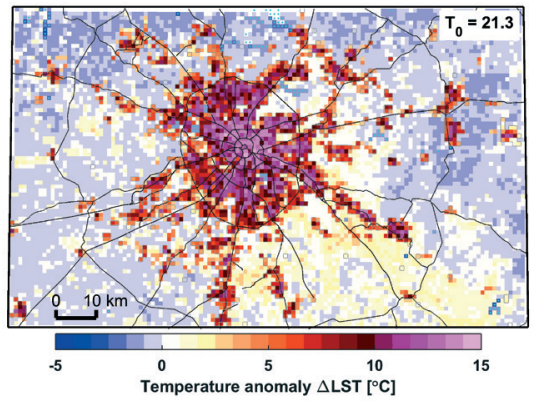

(c)

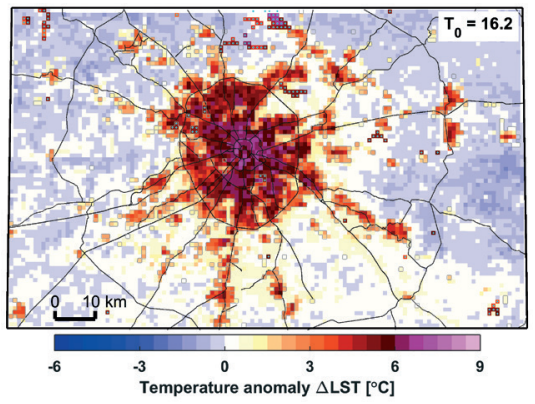

time modelled CLUHI is weakly correlated with urban area fraction, since the warmest areas are shifted to the south-east of the city and further to the south-eastern rural areas.

In order to quantify the relationships between the modelling results and remote sensing data, we present a comparison of the MODIS-derived LST values versus modelled LST and SAT values (Fig. 8). In contrast to the very good agreement between the modelling results and in situ observations (Figs. 5, 6) and general agreement between the model and MODIS data on the CLUHISUHI relationships discussed previously, the agreement between the modelled and MODIS-derived LST values is lower For the daytime conditions, in addition to significant overestimation of the SUHI intensity by the model, the spatial correlation between the modelled and observed LST values is quite weak $\left(R^{2} \approx 0.6\right.$ for all grid cells and only $\approx 0.4$ for urban grid cells) that results in the significant scatter of points in

(b)

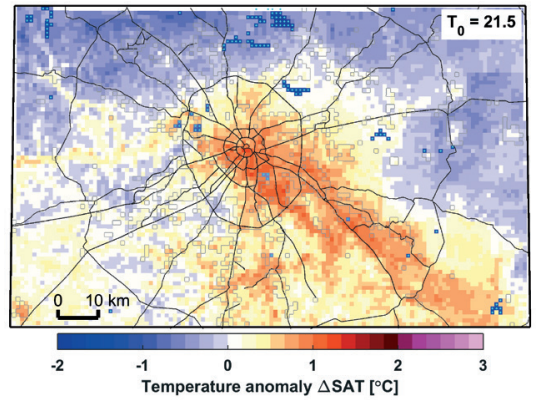

(d)

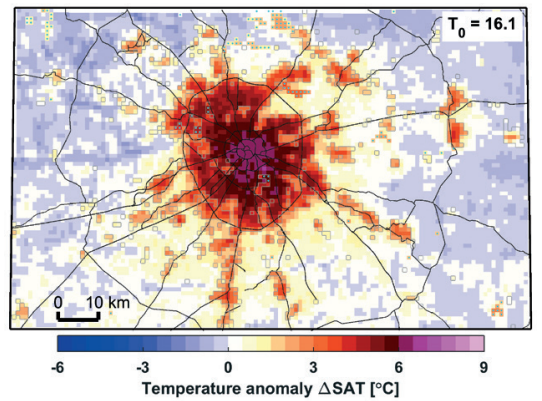

Fig. 7. Modelled fields of land surface temperature anomaly $\Delta$ LST $(\mathrm{a}, \mathrm{c})$ and surface air temperature anomaly $\triangle S A T(b, d)$, averaged over the moments of registration of the selected daytime $(a, b)$ and evening $(c, d)$ Terra images. Anomaly is defined as the departure from the mean rural LST/SAT value $\mathrm{T}_{0}$ (see details in text). Black lines indicate the primary highways according to OpenStreetMap data, gray contours indicate urban grid cells, cyan points indicate water grid cells. Note that the color scale is different for daytime SAT and LST field 
Fig. 8a. The correlation between modelled

and MODIS-derived LST is stronger for the evening and nighttime conditions (Fig. 8b, $c ; R^{2}>0.6$ both for rural and urban grid cells). However, the model slightly underestimates the LST spatial variability, especially for nighttime conditions (slope coefficient of the linear trend $k<1$ ). Surprisingly, even better agreement is found between the MODIS-derived LST and modelled SAT (Fig. $8 \mathrm{e}, \mathrm{f})$ in terms of the correlation $\left(R^{2}>0.8 \mathrm{for}\right.$ urban grid cells) and trend slope ( $\mathrm{k}$ is closer to 1). In other words, the SUHI in the field

(a) day (Terra)

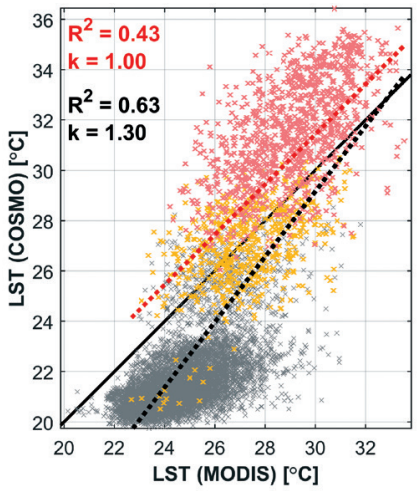

(d) day (Terra)

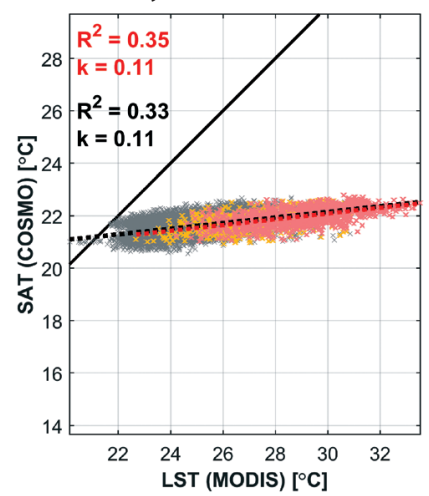

(b) evening (Terra)

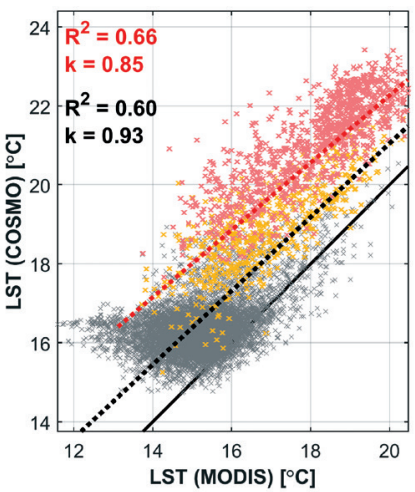

(e) evening (Terra)

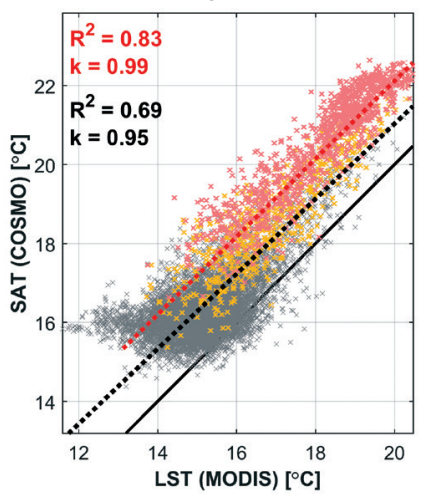

of the MODIS-derived LST is closer to the modelled CLUHI rather than the modelled SUHI. In contrast to nighttime conditions, the correlation between modelled SAT and MODIS-derived LST is very weak $\left(R^{2} \approx 0.3\right)$ for a daytime (Fig. 8d).

\section{DISCUSSION}

The presented results show substantial differences between CLUHI and SUHI, which are expressed in the diurnal course and spatial structure of the urban temperature (c) night (Aqua)

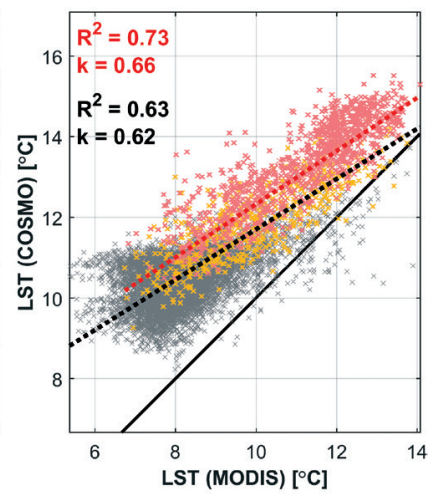

(f) night (Aqua)

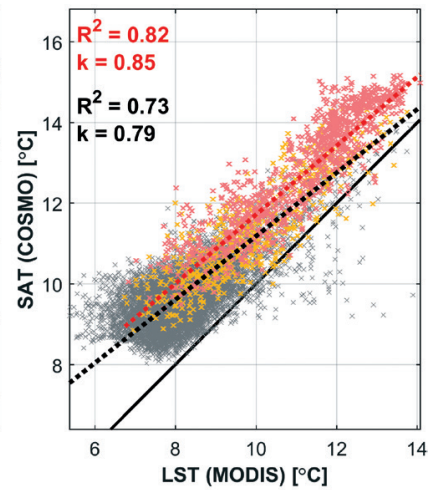

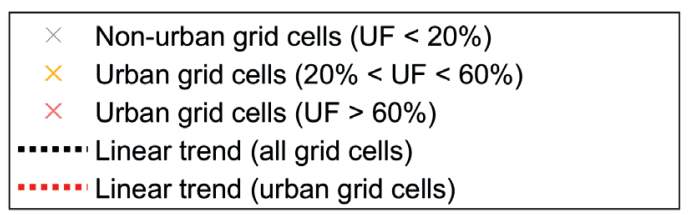

Fig. 8. Comparison of the MODIS-derived LST values and modelled LST (a-c) and SAT (d-e) values, averaged over the periods of registration of the selected satellite daytime $(a, d)$ and evening (b, e) Terra images and nighttime Aqua images (c, e). Water grid cells are excluded from the analysis. Dotted lines indicate the linear trends, built for all grid cells (black line) and only for urban grid cells with urban fraction $>20 \%$ (red line). Determination $\left(R^{2}\right)$ and slope $(k)$ coefficients for these trends are shown in each panel. 
anomalies. The SUHI is more pronounced during the day, while the CLUHI is more pronounced in the evening and night. The difference between CLUHI and SUHI was known before (Voogt and Oke 2003), however it is often not sufficiently considered in recent urban climate studies (see the literature review in the introduction). In addition, CLUHI-SUHI relationships are often considered separately from the physical processes in the atmospheric boundary layer (hereafter referred as ABL) and its lowest part, known as the surface layer.

The interpretation of the CLUHI-SUHI relationships with respect to the ABL processes is provided below. On a clear summer day, urban surfaces heat up more strongly in the countryside due to the smaller albedo, less heat consumption for evaporation, specific features of the urban geometry and other factors (Oke 1982; Ryu and Baik 2012), which determines a pronounced SUHI. However, in such conditions, atmospheric turbulence is well developed that determines the intensive mixing within the $A B L$, which reaches a height of $1-2 \mathrm{~km}$ during the day (Oke 1987). Intense vertical and horizontal turbulent mixing smoothens the local influence of various surface types on the thermal regime of the surface layer of the atmosphere, hence, weakens the CLUHI. At the same time, the intensive mixing leads to an intense redistribution of the daytime urban excess heating over the lower atmosphere up to $1 \mathrm{~km}$ above the ground (Wouters et al. 2013; Varentsov et al. 2018). Good mixing within a deep ABL results in the weakest correlation between the daytime SAT and LST values, which was also found beyond the UHI studies, e.g. in a regional study for Northeast China (Yang et al. 2017).

After sunset, the surface cools rapidly due to radiation cooling. The lower troposphere becomes stably stratified; the intensity of the vertical turbulent heat exchange between the surface-layer (canopy layer) and the upper atmosphere strongly decreases. The mixed-layer height is at least eight to ten times smaller during the night than during the day so that urban heat release is distributed over a significantly smaller depth (Bohnenstengel et al. 2011). As a result, the nighttime UHI over a megacity typically extents to the lower troposphere for 100-150 m only (Wouters et al. 2013; Varentsov et al. 2018). Within the canopy layer the UHI is much more intense at nighttime than at daytime. In contrast to a stable nighttime surface layer over rural areas, the stratification remains neutral in a surface layer over the city (Wouters et al. 2013) that means the near-zero SAT-LST difference. This explains the significantly better match between the CLUHI and SUHI at evening and night.

At the same time, the role of horizontal transport increases in the thin stable $A B L$, which affects the UHI spatial structure. During the day, the SUHI is mainly determined by local properties of the underlying surface, first of all, by the presence of impervious urban surfaces or pervious green-covered surfaces. These features determine the sharp LST gradients and presence of the several isolated hotspots within the city. At night, the non-local effects established by atmospheric advection (transport of excessive heat within the city or further downwind to the suburbs) and horizontal turbulent mixing become larger and lead to smoother temperature gradients and monocentric SUHI spatial structure with a temperature maximum in the city center. Such differences between daytime and nighttime SUHI spatial patterns are consistent with MODIS-derived results for other cities (Cheval and Dumitrescu 2015; Sun et al. 2015; Zhou et al. 2015). The nighttime SUHI spatial patterns for Moscow are also consistent with spatial patterns of CLUHI according to the in situ observations (Climate of Moscow... 2017).

The modelling results are generally consistent with mechanisms described and are in a good agreement with in situ observations on the CLUHI spatiotemporal variations. However, the simulated daytime SUHI intensity substantially exceeds the corresponding MODIS-derived values. The agreement between remote sensing data and modelling results is much better for the nighttime and evening conditions, but surprisingly the MODIS-derived SUHI cor- 
relates more strongly with the modelled CLUHI than with modelled SUHI.

A number of explanations could be proposed for such model behavior. Firstly, the remote sensing data for urban areas does not characterize the temperature of a horizontal Earth surface, but reflects the thermal conditions of the 3-dimensional urban canopy, which also includes shaded and unshaded walls, elements of street and yard greening, etc. Such objects are located above the surface that makes their temperatures closer to the surrounding air temperature. However, within the framework of the COSMO model and the TERRA_ URB scheme, the simulated LST reflects the state of a uniform horizontal surface, the properties of which are adjusted in such a way as to ensure the adequate reproduction of the components of the surface thermal balance and SAT. Secondly, the model uncertainties may be related with thermal and radiative properties of urban materials. These properties may be crucial for the SUHI intensity, but in our study they were defined as constants over the urban area because of the lack of information on urban materials. Such inaccuracies may be combined with uncertainties of other parameters, which are important for simulation of the surface energy balance and which were not verified in detail in previous studies for TERRA_URB scheme and other UCMs (e.g. the surface layer resistances or roughness length for temperature). Finally, the deficiencies of remote sensing data may lead to discrepancies between the LST fields, particularly because of the possible uncertainties of the emissivity mask that is used for LST calculation (Hu et al. 2014).

In either case, the revealed discrepancies between the model and observations should be investigated in more detail in further research, also with application of additional alternative observational products (e.g. remote sensing data of higher resolution, airplane-based and tower-based radiative measurements, in situ LST observations).

\section{CONCLUSION}

In the presented study, we have analyzed the summertime UHI effect for the city of Moscow using three independent approaches and corresponding datasets: the dense in situ SAT observations, MODIS remote sensing LST data and high-resolution mesoscale modelling with the COSMO-CLM model and urban canopy parameterization TERRA_URB. Comparison of these three approaches was made for the city of Moscow for the first time. The results of the comparison revealed the principal difference between urban SAT and LST anomalies (known as CLUHI or SUHI respectively), and between the daytime and nighttime CLUHI-SUHI relationships. The differences between CLUHI and SUHI are consistent with a general understanding of the $A B L$ processes and are confirmed by the modelling.

Generally, we found that the model and observations are in good agreement, particularly for daytime and nighttime CLUHI (in comparison with in situ observations), and for nighttime SUHI (in comparison with MODIS remote sensing data). However, the correspondence is substantially lower for the daytime SUHI, the intensity of which is substantially overestimated in the model. In addition, the modelled CLUHI corresponds to the observed SUHI surprisingly better than the modelled SUHI for evening and night.

The study appeals for further in-depth investigation of the feedbacks between the CLUHI, SUHI and $A B L$, including the development of the urban conceptual $A B L$ models for investigation of the role of the $A B L$ processes in the CLUHI-SUHI differences (e.g. Droste et al. 2018; Wouters et al. 2019); and for more comprehensive model verification studies for urban areas.

Finally, the presented results allow us to draw a number of recommendations about the applications of the considered temperature datasets in urban climate research and related fields.

1. The CLUHI is not equivalent to the SUHI, especially for daytime conditions. Accord- 
ingly, remote sensing LST data cannot be a direct and universal replacement of in situ SAT observations data for urban climate studies. However, there is a stronger consistency between the nighttime CLUHU and SUHI. Hence, any comparison of climatological statistics on the CLUHI and SUHI intensities should be done with a great accuracy and taking into consideration the different CLUHI-SUHI relationships for the daytime and nighttime conditions.

2. The mesoscale model coupled with urban canopy models are able to successfully simulate the urban climate features for such a big city as Moscow. However, the good agreement between the modelling results and in situ observations on the CLUHI features does not automatically mean the same good agreement between modelling results and MODIS data on the SUHI features. Despite the very good agreement in CLUHI, presented results highlight potential misunderstanding of the urban-atmosphere interaction processes. Tackling these issues could offer great potential to further improve the urban atmosphere feedbacks in mesoscale atmospheric modelling and our understanding of the urban climate system.

3. The application of the remote sensing data for verification of the mesoscale modelling results for urban areas requires accuracy and careful consideration of the specific features of the model parametrizations and satellite images. Therefore, we recommend to focus on such tasks firstly in the nighttime conditions, since at night the agreement between remote sensing data, in situ observations and modelling results on both types of $\mathrm{UHI}$ is much better than in the daytime conditions. If possible, an integrated and comprehensive approach to model verification should be applied, based on both in situ and remote sensing data.

The above mentioned does not belittle the importance of remote sensing data as one of the important data sources for urban climatology. In addition to the SUHI studies and the model verification, remote sensing LST data could be used for regression modeling of SAT and biometeorological comfort indices as one of the predictors (Ho et al. 2016), for estimating anthropogenic heat fluxes (Chrysoulakis et al. 2018), for the diagnosis and monitoring of urbanization processes (Shen et al. 2016; Tan et al. 2010b; Weng and Lu 2008), for mapping the development and functional zones of urban areas (Grishchenko and Ermilova 2018) and for integrated analysis of local climatic features together with the in situ measurements (Konstantinov et al. 2015; Cheval and Dumitrescu 2017). Since the agreement between CLUHI and SUHI increases in the absence of intense solar heating, remote sensing LST data becomes especially valuable for urban climate studies in nighttime conditions and in the conditions of mid-latitude and Arctic winter. In either case, the joint use of in situ, remote sensing and modelling data could increase the value of UHI and urban climate studies if the relationships between the different methods are taken into consideration.

\section{ACKNOWLEDGMENTS}

The major research (supercomputer modeling, processing of the satellite images, data management and analysis) performed by M.I. Varentsov and M.Yu. Grishchenko was funded by the grant program of Russian Science Foundation (project No. 1777-20070 "An initial assessment and projection of the bioclimatic comfort in Russian cities in XXI century against the context of climate change"). The work of Hendrik Wouters (discussing and interpreting the results, participation in writing the paper) was funded by the European Research Council (ERC) under Grant Agreement No. 715254 (DRY-2-DRY). The research was carried out using the equipment of the shared research facilities of HPC computing resources at Lomonosov Moscow State University. The authors are grateful to the administration and stuff of the Federal State Budgetary Institution "Central Administration of Hydrological and Environmental Monitoring" and to the administration and stuff of the Budgetary Environmental Protection Institution "Mosecomonitoring" for providing the data of meteorological observations used in the study. 


\section{Abbreviation list}

$\mathrm{ABL}$ - atmospheric boundary layer AWS - automatic weather station AAQS - automatic air quality station CLUHI - canopy-layer urban heat island COSMO - the atmospheric model, developed by Consortium for Small-Scale Modelling COSMO-CLM - the version of the COSMO model adapted for long-term simulations
LST - land surface temperature MODIS - Moderate Resolution Imaging Spectroradiometer MSU - Moscow State University SAT - surface air temperature SUHI - surface urban heat island UF - urban fraction UHI - urban heat island WMO - World Meteorological Organization WS - regular (non-automatic) weather station

\section{REFERENCES}

Baldina E. A., Grishchenko M. Yu. (2014). Interpretation of multi-temporal space imagery in thermal infrared band. Moscow University Vestnik. Series 5. Geography, 3, pp. 35-42 (in Russian with English summary).

Bohnenstengel S. I., Evans S., Clark P. A., and Belcher S. E. (2011). Simulations of the London urban heat island. Quarterly Journal of the Royal Meteorological Society, 137(659), pp. 1625-1640, DOI: 10.1002/qj.855.

Buechley R. W., Van Bruggen J., and Truppi L. E. (1972). Heat island = death island? Environmental Research, 5(1), pp. 85-92, DOl: 10.1016/0013-9351(72)90022-9.

Cheval S. and Dumitrescu A. (2015). The summer surface urban heat island of Bucharest (Romania) retrieved from MODIS images. Theoretical and Applied Climatology, 121(3-4), pp. 631-640, DOI: 10.1007/s00704-014-1250-8.

Cheval S. and Dumitrescu A. (2017). Rapid daily and sub-daily temperature variations in an urban environment. Climate Research, 73(3), pp. 233-246. DOI: 10.3354/cr01481.

Choi Y.-Y., Suh M.-S., and Park K.-H. (2014). Assessment of Surface Urban Heat Islands over Three Megacities in East Asia Using Land Surface Temperature Data Retrieved from COMS. Remote Sensing, 6(6), pp. 5852-5867, DOI: 10.3390/rs6065852.

Chrysoulakis N., Grimmond S., Feigenwinter C., Lindberg F., Gastellu-Etchegorry J.-P., Marconcini M., Mitraka Z., Stagakis S., Crawford B., Olofson F., Landier L., Morrison W., and Parlow E. (2018). Urban energy exchanges monitoring from space. Scientific Reports, 8(1), p. 11498, DOI: 10.1038/s41598-018-29873-x.

Cox W. (2018). Demographia World Urban Areas (World Agglomerations). Wendel Cox Consultancy, Illinois (14th Annual Edition). Belleville, Illinois. URL: http://www.demographia. com/db-worldua.pdf.

Davies M., Steadman P., and Oreszczyn T. (2008). Strategies for the modification of the urban climate and the consequent impact on building energy use. Energy Policy, 36(12), pp. 4548-4551, DOI: 10.1016/j.enpol.2008.09.013. 
Dee D. P., Uppala S. M., Simmons A. J., Berrisford P., Poli P., Kobayashi S., Andrae U., Balmaseda M. A., Balsamo G., Bauer P., Bechtold P., Beljaars A. C. M., van de Berg L., Bidlot J., Bormann N., Delsol C., Dragani R., Fuentes M., Geer A. J., Haimberger L., Healy S. B., Hersbach H., Holm E. V., Isaksen L., Kållberg P., Köhler M., Matricardi M., Mcnally A. P., Monge-Sanz B. M., Morcrette J. J., Park B. K., Peubey C., de Rosnay P., Tavolato C., Thepaut J. N., and Vitart F. (2011). The ERA-Interim reanalysis: Configuration and performance of the data assimilation system. Quarterly Journal of the Royal Meteorological Society, 137(656), pp. 553-597, DOl: 10.1002/qj.828.

Doms G., Förstner J., Heise E., Herzog H.-J., Mironov D., Raschendorfer M., Reinhardt T., Ritter B., Schrodin R., Schulz J.-P., and Vogel G. (2011). A description of the nonhydrostatic regional COSMO model. Part II: Physical parameterization. Deutscher Wetterdienst.

Dousset B., Gourmelon F., Laaidi K., Zeghnoun A., Giraudet E., Bretin P., Mauri E., and Vandentorren S. (2011). Satellite monitoring of summer heat waves in the Paris metropolitan area. International Journal of Climatology, 31(2), pp. 313-323, DOl: 10.1002/joc.2222.

Droste A. M., Steeneveld G. J., and Holtslag A. A. M. (2018). Introducing the urban wind island effect. Environmental Research Letters, 13(9), p. 94007. DOl: 10.1088/1748-9326/ aad8ef.

Emelina S. V., Konstantinov P. I., Malinina E. P., and Rubinshtein K. G. (2014). Evaluation of the informativeness of several biometeorological indices for three areas of the European part of Russia. Russian Meteorology and Hydrology, 39(7), pp. 448-457, DOI: 10.3103/ S1068373914070036.

Esau I. and Miles V. (2016). Warmer urban climates for development of green spaces in northern Siberian cities. Geography, Environment, Sustainability, 9(4), pp. 48-62, DOI: 10.24057/2071-9388-2016-9-4-48-62.

Flanner M. G. (2009). Integrating anthropogenic heat flux with global climate models. Geophysical Research Letters, 36(2), L02801, DOI: 10.1029/2008GL036465.

GCOS (2010). Implementation plan for the global observing system for climate in support of the UNFCCC (2010 update). GCOS Rep. 138, 186 pp. URL: https://library.wmo.int/doc_ num.php?explnum_id=3851.

Gornyy V. I., Lyalko V. I., Kritsuk S. G., Latypov I. S., Tronin A. A., Filippovich V. E., Stankevich S. A., Brovkina O. V., Kiselev A. V., Davidan T. A., Lubsky N. S., and Krylova A. B. (2016). Forecast of Saint-Petersburg and Kiev thermal replies on climate change (on the basis of EOS and Landsat satellite imagery). Current Problems in Remote Sensing of the Earth from Space, 13(2), pp. 176-191, DOI: 10.21046/2070-7401-2016-13-2-176-191. (in Russian with English summary).

Grishchenko M. Y. and Ermilova Y. V. (2018). Mapping of the built-up areas of Russian Arctic biggest cities using satellite imagery of various spatial resolution. Geodesy and Cartography, 933(3), pp. 23-34, DOI: 10.22389/0016-7126-2018-933-3-23-34. (in Russian with English summary).

Grishchenko M. Y. (2012). ETM+ thermal infrared imagery application for Moscow urban heat island study. Current Problems in Remote Sensing of the Earth from Space, 9(4), pp. 95-101. (in Russian with English summary). 
Ho H. C., Knudby A., Xu Y., Hodul M., and Aminipouri M. (2016). A comparison of urban heat islands mapped using skin temperature, air temperature, and apparent temperature (Humidex), for the greater Vancouver area. Science of The Total Environment, 544, pp. 929938, DOI: 10.1016/j.scitotenv.2015.12.021.

Hu L., Brunsell N.A., Monaghan A.J., Barlage M., and Wilhelmi O.V. (2014). How can we use MODIS land surface temperature to validate long-term urban model simulations? Journal of Geophysical Research Atmospheres, 119(6), pp. 3185-3201, DOI: 10.1002/2013JD021101.

Kislov A.V., ed. (2017). Climate of Moscow in conditions of global warming. Moscow, Russia: Publishing house of Moscow University. 288 pp. (in Russian).

KrayenhoffE. S., Moustaoui M., Broadbent A. M., Gupta V., and Georgescu M. (2018). Diurnal interaction between urban expansion, climate change and adaptation in US cities. Nature Climate Change, 8(12), pp. 1097-1103, DOI: 10.1038/s41558-018-0320-9.

Konstantinov P. I., Grishchenko M. Y., and Varentsov M. I. (2015). Mapping urban heat islands of arctic cities using combined data on field measurements and satellite images based on the example of the city of Apatity (Murmansk Oblast). Izvestiya - Atmospheric and Ocean Physics, 51(9), pp. 992-998, DOl: 10.1134/S000143381509011X.

Konstantinov P., Varentsov M., and Esau I. (2018). A high density urban temperature network deployed in several cities of Eurasian Arctic. Environmental Research Letters, 13(7), p. 75007, DOI: 10.1088/1748-9326/aacb84.

Lemonsu A. and Masson V. (2002). Simulation of a summer urban breeze over Paris. Boundary-Layer Meteorology, 104(3), pp. 463-490, DOI: 10.1023/A:1016509614936.

Lokoshchenko M. A. (2014). Urban "heat island" in Moscow. Urban Climate, 10, Part 3, pp. 550-562, DOI: 10.1016/j.uclim.2014.01.008.

Mariani L., Parisi S. G., Cola G., Lafortezza R., Colangelo G., and Sanesi G. (2016). Climatological analysis of the mitigating effect of vegetation on the urban heat island of Milan, Italy. Science of the Total Environment, 569-570, pp. 762-773, DOl: 10.1016/j.scitotenv.2016.06.111.

Martilli A., Clappier A., and Rotach M. W. (2002). An urban surface exchange parameterization for mesoscale models. Boundary-Layer Meteorology, 104, pp. 261-304, DOI: 10.1023/A:1016099921195.

Masson V. (2000). A physically based scheme for the urban energy budget in atmospheric models. Boundary Layer Meteorology, 94(3), pp. 357-397, DOI: 10.1023/A:1002463829265.

Miles V. and Esau I. (2017). Seasonal and Spatial Characteristics of Urban Heat Islands (UHIs) in Northern West Siberian Cities. Remote Sensing, 9(10), p. 989, DOI: 10.3390/rs9100989.

Muller C.L., Chapman L., Grimmond C.S.B., Young D.T., and Cai X. (2013). Sensors and the city: A review of urban meteorological networks. International Journal of Climatology, 33(7), pp. 1585-1600, DOI: 10.1002/joc.3678.

Oke T.R. (1982). The energetic basis of the urban heat island. Quarterly Journal of the Royal Meteorological Society, 108(455), pp. 1-24, DOl: 10.1002/qj.49710845502.

Oke T. R. (1987). Boundary layer climates (2nd ed.). Routledge. 435 pp. 
Peng S., Piao S., Ciais P., Friedlingstein P., Ottle C., Bréon F.-M., Nan H., Zhou L., and Myneni R.B. (2012). Surface Urban Heat Island Across 419 Global Big Cities. Environmental Science and Technology, 46(2), pp. 696-703, DOl: 10.1021/es301245j.

Peterson T.C. (2003). Assessment of Urban Versus Rural In Situ Surface Temperatures in the Contiguous United States: No Difference Found. Journal of Climate, 16(18), pp. 2941-2959, DOI: 10.1175/1520-0442(2003)016<2941:AOUVRI>2.0.CO;2.

Rockel B., Will A., and Hense A. (2008). The regional climate model COSMO-CLM (CCLM). Meteorologische Zeitschrift, 17(4), pp. 347-348, DOI: 10.1127/0941-2948/2008/0309.

Ryu Y.-H., and Baik J.-J. (2012). Quantitative Analysis of Factors Contributing to Urban Heat Island Intensity. Journal of Applied Meteorology and Climatology, 51 (5), pp. 842-854, DOI: 10.1175/JAMC-D-11-098.1.

Samsonov T.E., Konstantinov P.I., and Varentsov M.I. (2015). Object-oriented approach to urban canyon analysis and its applications in meteorological modeling. Urban Climate, 13, pp. 122-139, DOI: 10.1016/j.uclim.2015.07.007.

Samsonov T.E. and Trigub K. S. (2018). Mapping of local climate zones of Moscow city. Geodesy and Cartography, 936(6), pp. 4-25, DOl: 10.22389/0016-7126-2018-936-6-14-25 (in Russian with English summary).

Shen H., Huang L., Zhang L., Wu P., and Zeng C. (2016). Long-term and fine-scale satellite monitoring of the urban heat island effect by the fusion of multi-temporal and multisensor remote sensed data: A 26-year case study of the city of Wuhan in China. Remote Sensing of Environment, 172, 109-125, DOI: 10.1016/j.rse.2015.11.005.

Sheng L., Tang X., You H., Gu Q., and Hu H. (2017). Comparison of the urban heat island intensity quantified by using air temperature and Landsat land surface temperature in Hangzhou, China. Ecological Indicators, 72, pp. 738-746, DOI: 10.1016/j.ecolind.2016.09.009.

Sobrino J.A., Oltra-Carrió R., Sòria G., Bianchi R., and Paganini M. (2012). Impact of spatial resolution and satellite overpass time on evaluation of the surface urban heat island effects. Remote Sensing of Environment, 117, pp. 50-56, DOI: 10.1016/j.rse.2011.04.042.

Stewart I. D. and Kennedy C. A. (2017). Metabolic heat production by human and animal populations in cities. International Journal of Biometeorology, 61(7), pp. 1159-1171, DOI: 10.1007/s00484-016-1296-7.

Stewart I.D. and Oke T.R. (2012). Local climate zones for urban temperature studies. Bulletin of the American Meteorological Society, 93(12), pp. 1879-1900. DOI: 10.1175/ BAMS-D-11-00019.1.

Sun H., Chen Y., and Zhan W. (2015). Comparing surface- and canopy-layer urban heat islands over Beijing using MODIS data. International Journal of Remote Sensing, 36(21), pp. 5448-5465, DOl: 10.1080/01431161.2015.1101504.

Tan J., Zheng Y., Tang X., Guo C., Li L., Song G., Zhen X., Yuan D., Kalkstein A. J., Li F., and Chen H. (2010a). The urban heat island and its impact on heat waves and human health in Shanghai. International Journal of Biometeorology, 54(1), pp. 75-84, DOI: 10.1007/s00484009-0256-x

Tan K.C., Lim H.S., MatJafri M.Z., and Abdullah K. (2010b). Landsat data to evaluate urban expansion and determine land use/land cover changes in Penang Island, Malaysia. Environmental Earth Sciences, 60(7), pp. 1509-1521, DOI: 10.1007/s12665-009-0286-z. 
Varentsov M.I., Samsonov T.E., Kislov A.V., and Konstantinov P.I. (2017a). Simulations of Moscow agglomeration heat island within framework of regional climate model COSMOCLM. Moscow University Vestnik. Series 5. Geography, 6, pp. 25-37 (in Russia with English summary).

Varentsov M.I., Konstantinov P.I., and Samsonov T.E. (2017b). Mesoscale modelling of the summer climate response of Moscow metropolitan area to urban expansion. IOP Conference Series: Earth and Environmental Science, 96, p. 12009, DOI: 10.1088/17551315/96/1/012009.

Varentsov M., Wouters H., Platonov V., and Konstantinov P. (2018). Megacity-Induced Mesoclimatic Effects in the Lower Atmosphere: A Modeling Study for Multiple Summers over Moscow, Russia. Atmosphere, 9(2), p. 50, DOI: 10.3390/atmos9020050.

Vil'fand R. M., Rivin G.S., and Rozinkina I.A. (2010). COSMO-RU system of nonhydrostatic mesoscale short-range weather forecast of the hydrometcenter of Russia: The first stage of realization and development. Russian Meteorology and Hydrology, 35(8), pp. 503-514, DOI: $10.3103 /$ S1068373910080017.

Voogt J. and Oke T.R. (2003). Thermal remote sensing of urban climates. Remote Sensing of Environment, 86(3), pp. 370-384, DOI: 10.1016/S0034-4257(03)00079-8.

Weng Q. and Lu D. (2008). A sub-pixel analysis of urbanization effect on land surface temperature and its interplay with impervious surface and vegetation coverage in Indianapolis, United States. International Journal of Applied Earth Observation and Geoinformation, 10(1), pp. 68-83, DOl: 10.1016/j.jag.2007.05.002.

Wouters H., De Ridder K., Demuzere M., Lauwaet D., and Van Lipzig N. P. M. (2013). The diurnal evolution of the urban heat island of Paris: A model-based case study during Summer 2006. Atmospheric Chemistry and Physics, 13(17), pp. 8525-8541. DOI: 10.5194/ acp-13-8525-2013.

Wouters H., De Ridder K., Poelmans L., Willems P., Brouwers J., Hosseinzadehtalaei P., Tabari H., Vanden Broucke S., van Lipzig N. P. M., and Demuzere M. (2017). Heat stress increase under climate change twice as large in cities as in rural areas: A study for a densely populated midlatitude maritime region. Geophysical Research Letters, 44(17), pp. 8997-9007. DOI: 10.1002/2017GL074889.

Wouters H., Demuzere M., Blahak U., Fortuniak K., Maiheu B., Camps J., Tielemans D., and van Lipzig N. P. M. (2016). The efficient urban canopy dependency parametrization (SURY) V1.0 for atmospheric modelling: description and application with the COSMO-CLM model for a Belgian summer. Geoscientific Model Development, 9(9), pp. 3027-3054, DOI: 10.5194/ gmd-9-3027-2016.

Wouters H., Petrova I.Y., van Heerwaarden C.C., Vilà-Guerau de Arellano J., Teuling A.J., Meulenberg V., Santanello J. A., and Miralles D.G. (2019). Atmospheric boundary layer dynamics from balloon soundings worldwide: CLASS4GL v1.0. "Geoscientific Model Development, 12 (12), pp. 2139-2153, DOI: 10.5194/gmd-12-2139-2019"

Yang Y.Z., Cai W.H., and Yang J. (2017). Evaluation of MODIS land surface temperature data to estimate near-surface air temperature in Northeast China. Remote Sensing, 9(5), p. 410, DOI: 10.3390/rs9050410.

Zhou B., Rybski D., and Kropp J.P. (2013). On the statistics of urban heat island intensity. Geophysical Research Letters, 40(20), pp. 5486-5491, DOI: 10.1002/2013GL057320. 
Zhou B., Rybski D., and Kropp J. P. (2017). The role of city size and urban form in the surface urban heat island. Scientific Reports, 7(1), p. 4791, DOl: 10.1038/s41598-017-04242-2.

Zhou D., Xiao J., Bonafoni S., Berger C., Deilami K., Zhou Y., Frolking S., Yao R., Qiao Z., and Sobrino J. (2018). Satellite Remote Sensing of Surface Urban Heat Islands: Progress, Challenges, and Perspectives. Remote Sensing, 11(1), p. 48, DOI: 10.3390/rs11010048.

Zhou D., Zhao S., Zhang L., Sun G., and Liu Y. (2015). The footprint of urban heat island effect in China. Scientific Reports, 5, pp. 2-12, DOI: 10.1038/srep11160.

Received on January $22^{\text {nd }}, 2019$

Accepted on May $17^{\text {th }}, 2019$

Received on January 22 , 2019 